\title{
On the Occurrence of Four Diatom Taxa from Eastern India with a Taxonomic Note
}

\author{
Jai Prakash Keshri, ${ }^{1}$ Amit K. Ghosh, ${ }^{2}$ and Surajit Roy ${ }^{1}$ \\ ${ }^{1}$ CAS in Botany, University of Burdwan, Golapbag, Burdwan, West Bengal 713104, India \\ ${ }^{2}$ Birbal Sahni Institute of Palaeobotany, 53 University Road, Lucknow, Uttar Pradesh 226 007, India
}

Correspondence should be addressed to Jai Prakash Keshri; keshrijp@gmail.com

Received 26 October 2015; Revised 12 February 2016; Accepted 14 February 2016

Academic Editor: Curtis C. Daehler

Copyright (C) 2016 Jai Prakash Keshri et al. This is an open access article distributed under the Creative Commons Attribution License, which permits unrestricted use, distribution, and reproduction in any medium, provided the original work is properly cited.

Diatoms were collected from the Kotulpur area of West Bengal. Four diatom taxa, namely, Eunotia minor (Kützing) Grunow, Achnanthidium minutissimum (Kützing) Czarnecki, Lemnicola hungarica (Grunow) Round and Basson, and Navicula radiosa Kützing were observed using scanning electron microscopy (SEM) and identified in light of modern diatom taxonomic trends. Except Eunotia minor, all these taxa are new records to Eastern India. A note on the taxonomy of Achnanthes pseudobiasolletiana as described by Gandhi and Eunotia serrata var. diadema (Ehr.) R. M. Patrick as reported by Dwivedi and Misra has been added.

\section{Introduction}

Diatoms are a very important group of algae as they are the most common producers of organic matter in water bodies. According to Prygiel et al. [1] diatoms are good bioindicators responding quickly to environmental changes. During the 19th century, diatoms were studied for the first time in India by Ehrenberg [2]. Subsequent notable works were made by Skvortzow [3], Biswas [4], Krishnamurthy [5], Venkataraman [6], and Sarode and Kamat [7] as well as 34 papers with a book on diatom taxonomy by Gandhi [8].

Though several hundreds of papers dealing with diatom taxonomy of Indian regions were published, most of them are limited to line drawings or bright field microscopic images, which have limited information on the ultrastructural details of diatoms. Further, some of the taxa have broad species concepts and follow an old classification system. The main reason behind these taxonomic identification problems was the scarcity of ultramodern scanning and light microscopes and up to date scientific literature.

The work on Indian fresh water diatoms is still in an early stage, but breakthroughs were initiated by Karthick and Kociolek [9-11], Karthick et al. [12-14], and Alakananda et al. $[15,16]$ and to some extent by Wojtal et al. [17] and Roy and Keshri [18] following modern trends of diatom taxonomy.
The main purpose of this study was to examine the diatom diversity of eastern India in light of current systematic trends. Since diatom studies in eastern India were done very sporadic (Skvortzow [3], Prasad et al. [19], and Roy and Keshri [18]), this study adds new information on the diversity and taxonomy of this group in this part of the globe.

\section{Materials and Methods}

2.1. Study Area and Sample Collection. The study area covered small ponds of Kotulpur from Bankura district in West Bengal, India. Kotulpur is situated at $23.0125^{\circ} \mathrm{N}$ latitude and $87.5936^{\circ} \mathrm{E}$ longitude. Diatom materials were collected from Kotulpur on 24.10.2014. Epiphytic, epilithic, and episammic materials were collected and preserved in $70 \%$ ethanol.

2.2. Cleaning Techniques and Microscopy. Subsamples were cleaned using 30\% hydrogen peroxide solution for removal of organic coatings. These procedures are modified from the techniques of Krammer and Lange-Bertalot [20], Taylor et al. [21], and Karthick et al. [22]. Cleaned samples were then centrifuged at $3000 \mathrm{rpm}$ and alternatively rinsed with distilled water 3-4 times to remove of traces of hydrogen peroxide from samples. 


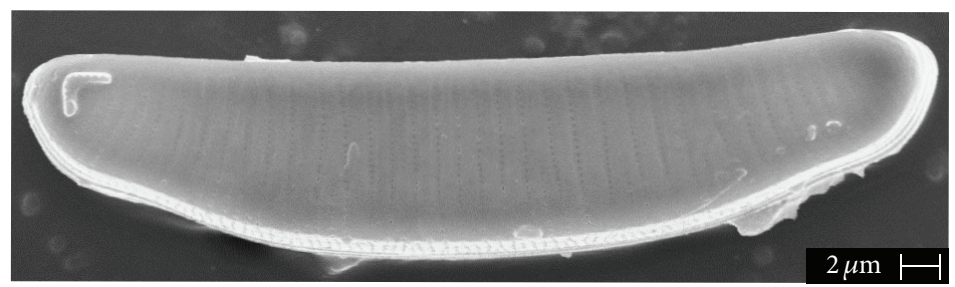

(a)

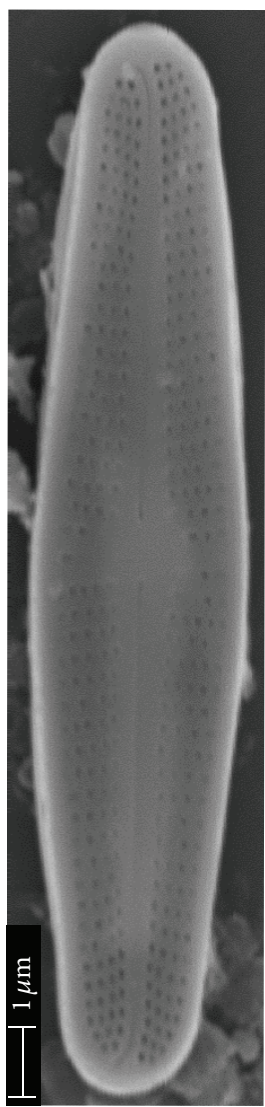

(b)

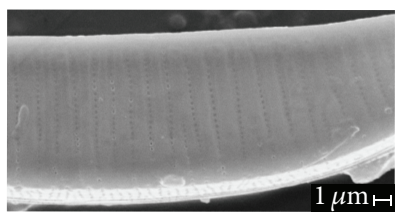

(c)

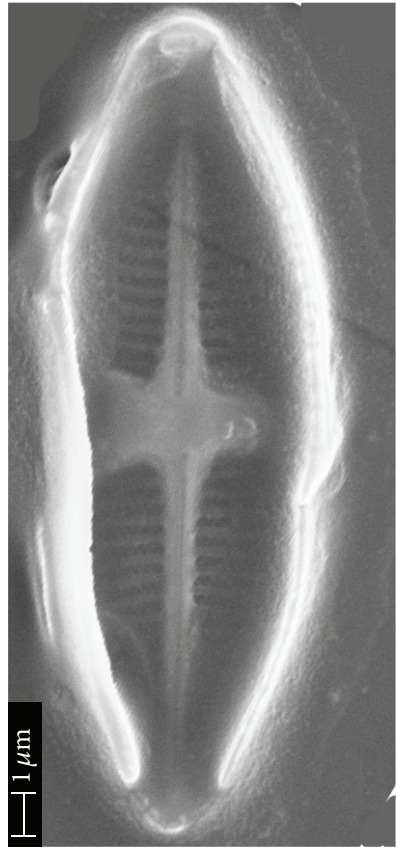

(d)

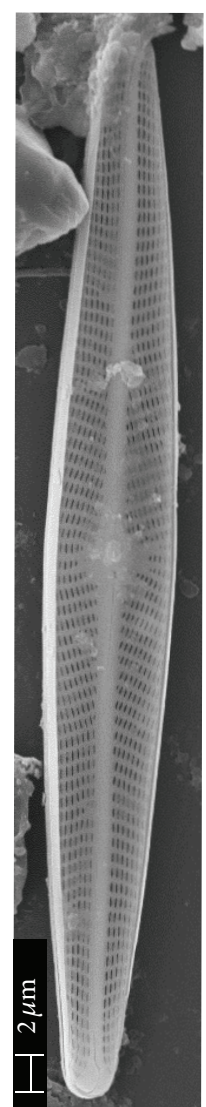

(e)

Figure 1: ((a) and (c)) Eunotia minor (Kützing) Grunow. (b) Achnanthidium minutissimum (Kützing) Czarnecki. (d) Lemnicola hungarica (Grunow) Round and Basson. (e) Navicula radiosa Kützing (scale bar shown in each SEM figure individually).

The standard protocol was followed for light microscopic and scanning electron microscope (SEM) studies. SEM studies were carried out using a LEO 430 SEM located at the Birbal Sahani Institute of Paleobotany, Lucknow.

The collected preserved materials, along with the permanent slides made up with diatom mounting medium, were stored in the Herbarium of Phycology laboratory in the department of Botany, The University of Burdwan for future study and reference purpose (BURD-JPK 2066 dated: 24.10.2014).

\section{Results}

Systematic descriptions and identification of the diatoms have been done using standard literature including Buczkó [23], Carneiro and de Campos Bicudo [24], Karthick et al. [25],
Krammer and Lange-Bertalot [26], Patrick and Reimer [27], Lange-Bertalot [28], Lange-Bertalot and Metzeltin [29], Round and Basson [30], and Wojtal et al. [31].

According to the classification proposed by Round et al. [32] and Medlin and Kaczmarska [33] the observed diatoms belong to subdivision Bacillariophytina and class Bacillariophyceae.

\subsection{Eunotia minor (Kützing) Grunow (Family: Eunotiaceae)} (Figures 1(a) and 1(c)). (Krammer and Lange-Bertalot [26], p. 196, fig. 142: 7-15; Lange-Bertalot and Metzeltin [29], p. 144, fig. 13: 18-21, fig. 103: 11; Karthick et al. [25], pl. 29).

Synonyms. Himantidium minus Kützing, Himantidium pectinale var. minus (Kützing) Rabenhorst, Himantidium pectinale var. minus (Kützing) Grunow, Eunotia pectinalis var. minor 
(Kützing) Rabenhorst, Eunotia pectinalis f. minor (Kützing) Müller, Eunotia pectinalis f. minor (Kützing) Berg.

SEM Morphology. Convex dorsal and slightly concave or almost straight ventral margin, valve apices bluntly rounded or largely rounded, lunate shaped in valve view, striae uniseriate, taxon specific widely spaced striae present at the centre but slightly more dense towards the apices; valve length: $53.5 \mu \mathrm{m}$, valve breadth: $10.5-10.8 \mu \mathrm{m}$, striae density: $7-10 / 10 \mu \mathrm{m}$.

Distribution. Peninsular India (Karthick et al. [25]) as E. minor Kalimpong, West Bengal (Prasad et al. [19]); Jog Falls of Mysore, Karnataka (Gandhi [34]); Katta, Chandrapur, Bhandara, Maharashtra (Sarode and Kamat [35]) as Eunotia pectinalis var. minor.

It is common in habitats of India and almost cosmopoli$\tan$ in distribution.

3.2. Achnanthidium minutissimum (Kützing) Czarnecki (Family: Achnanthidiaceae) (Figure 1(b)). (Wojtal et al. [31], p. 214, figs. 1-15; Karthick et al. [25], pl. 21).

Synonyms. Achnanthes minutissima Kützing, Achnanthes microcephala (Kützing) Grunow, Achnanthes minutissima var. cryptocephala Grunow, Achnanthes minutissima f. cryptocephala Grunow, Achnanthes minutissima f. curta Grunow, Achnanthes cryptocephala (Grunow) Peragallo, Achnanthes minutissima var. genuine Cleve-Euler.

SEM Morphology. Valves with bilateral symmetry. Valves are linear-lanceolate with rounded, subrostrate apices. Heterovalves flexed across the transapical axis. Raphe system present only on one valve. Raphe valves with narrow, linearlanceolate axial area broadening in the center to form a transverse irregularly shaped central area. Raphe filiform, straight, with proximal raphe ends dilated and distal raphe endings subtly unilaterally curved. Striae moderately radiate on both valves with two shortened striae on either side of central area. Striae composed of up to 6 areolae per stria. Sometimes slit-like areola present on the valve margins. Valve length: $15.9 \mu \mathrm{m}$, valve breadth: $3.3 \mu \mathrm{m}$, and striae density: $32-$ $34 / 10 \mu \mathrm{m}(\mathrm{RV})$.

Distribution. Peninsular India (Karthick et al. [25]) as A. minutissimum. Jog Falls of Mysore, Karnataka (Gandhi [36]); Katta, Mansar, Maharashtra (Sarode and Kamat [35]) as A. minutissima var. cryptocephala. Fountain Reservoirs of Seth Sarabhai's Garden, Ahmedabad, Gujarat (Gandhi [37]) as A. minutissima f. cryptocephala. Vasna village, Ahmedabad, Gujarat (Gandhi [38]); Kolhapur, Maharashtra (Gandhi [39]); Bombay, Maharashtra (Gandhi [40]); Aurangabad, Maharashtra (Sarode and Kamat [41]) and Nagpur, Maharashtra (Sarode and Kamat [42]) as A. minutissima. Hirebhasgar Dam area, Mysore, Karnataka (Gandhi [43]); Bombay, Maharashtra (Gandhi [44]); Lonavla, Maharashtra (Gandhi [40]); Khamgaon, Maharashtra (Sarode and Kamat [35]) as A. microcephala. Hyderabad, Telengana (Johnson [45]) as A. minutissima and A. minutissima var. cryptocephala.
It is common in habitats of different parts of India but this is the first report of the taxon from Eastern India.

3.3. Lemnicola hungarica (Grunow) Round and Basson (Family: Achnanthidiaceae) (Figure 1(d)). (Round and Basson [30], p. 77, figs. 4-7, 26-31; Buczkó [23], figs. $2 \mathrm{a}-\mathrm{k}, 3 \mathrm{a}-\mathrm{h}, 4 \mathrm{a}$, 7; Carneiro and de Campos Bicudo [24], p. 255, figs. 2-9; Karthick et al. [25], pl. 25).

Synonyms. Achnanthidium hungaricum Grunow, Achnanthes hungarica (Grunow) Grunow.

SEM Morphology. Valves with bilateral symmetry. Valves linear-lanceolate with cuneate poles with subrostrate apices. Raphe valve with often asymmetrical stauros and linear axial area. The wider part of the stauros having a "horse-shoe" depression. Raphe system present only on one valve. Terminal raphe fissures are short, slightly expanded and turned toward opposite sides. Central raphe endings are curved to opposite sides internally. Striae are biseriate and slightly radiate in the valve center but strongly radiate at the apices. Valve length: $19.5 \mu \mathrm{m}$, valve breadth: $7.6 \mu \mathrm{m}$, striae density: $16-17 / 10 \mu \mathrm{m}$ (RV).

Distribution. Peninsular India (Karthick et al. [25]); Salsette island, Bombay, Maharashtra (Gonzalves and Gandhi [46]); Lonavla, Maharashtra (Gandhi [40]); Badrinath, Uttarakhand (Suxena and Venkateswarlu [47]); Kodaikanal Hill, Tamil Nadu (Suxena [48]) and Bhandara, Maharashtra (Sarode and Kamat [35]) as A. hungarica.

It is not very common in habitats of India and this is the first report of the taxon from Eastern India.

3.4. Navicula radiosa Kützing (Family: Naviculaceae) (Figure 1(e)). (Patrick and Reimer [27], p. 509, 560-561 figs. 48:15; Lange-Bertalot [28], p. 59, figs. 8:1-7, figs. 67:1-2).

Synonyms. Navicula gracilis var. radiosa (Kützing) Rabenhorst, Pinnularia radiosa W. Smith, Navicula radiosa var. acuta (W. Smith) Grunow.

SEM Morphology. Valves with bilateral symmetry. Valves are narrow and lanceolate, ends acutely rounded. Central area is rhomic. The striae are strongly radiate and are bent in the valve center and convergent near the poles. Striae composed of lineolae. Valve length: $61 \mu \mathrm{m}$, valve breadth: $7.7 \mu \mathrm{m}$, striae density: $12 / 10 \mu \mathrm{m}$, lineolae: $33-35 / 10 \mu \mathrm{m}$.

Distribution. Peninsular India (Karthick et al. [25]); Maharashtra (Sarode and Kamat [7]); Kolhapur, Maharashtra (Gandhi [39]) and Lonavla, Maharashtra (Gandhi [40]) as N. radiosa.

It is a common and widely spread taxon but reported for the first time from Eastern India.

\section{Discussion}

Except for the work of Skvortzow [3] no significant contribution has been published on the freshwater diatoms of Eastern 
India. To some extent the research on the freshwater diatoms of Gujarat and Maharashtra as done by Gandhi [8] and Sarode and Kamat [7] could be mentioned, but this was limited in taxonomic scope. Since the advent of SEM that changed diatom taxonomy radically, notable contributions have been very few (Karthick and Kociolek [9-11], Karthick et al. [1214], Alakananda et al. [15, 16], Wojtal et al. [17] and Roy and Keshri [18]). In this light the four taxa as observed under SEM from Eastern India appear to be significant because except $E$. minor, all the taxa are new records to Eastern India. From this study it also appears that the distributional records of diatoms are to be checked in light of modern diatom taxonomy, since several diatom taxa show endemism. Notably our knowledge of the diatoms of South East Asia is very poor as the published literature shows. Moreover the existing knowledge of diatoms of India should be re-evaluated in above mentioned perview. This is because in many papers, mere listing has been done, and in several other cases identifications have been done very reluctantly. This has created confusion in actual biodiversity records.

It also appears that there is the need for taxonomic revisions in many taxonomic groups. For example Gandhi [49] in his paper reported a new taxon to science as Achnanthes pseudobiasolletiana but from the camera lucida drawings, description, and measurements it is none other than $A$. minutissimum as appears in the light of modern taxonomy. Similarly there is confusion regarding the taxonomy of Achnanthidium minutissimum sensu lato as available in the literature of the works of Indian authors and abroad. A. minutissimum sensu stricto nowadays has a better circumscription with finer ultrastructural details, and more detailed study of Indian populations may show new taxa distinctly different from A. minutissimum. In one paper of Dwivedi and Misra [50] they identified taxa as Eunotia serrata var. diadema (Ehr.) R. M. Patrick but in the photographic girdle view image the taxa looks like a rectangular box which is one of the characteristic feature of E. minor (Karthick et al. [25]), so we propose it should be considered as E. minor.

\section{Conflict of Interests}

The authors of the paper declare that there is no conflict of interests regarding its publication.

\section{Acknowledgments}

Special thanks are due to our revered teacher Professor Pranjit Sarma (retired), Department of Botany, The University of Burdwan (West Bengal, India), for his constant encouragement during the work throughout. The financial assistance provided by the UGC, laboratory facilities provided by the Head, Department of Botany, The University of Burdwan are gratefully acknowledged. Thanks are also due to the Director, BSIP, for SEM and other facilities (BSIP/RDCC/Publication number 82/2015-16).

\section{References}

[1] J. Prygiel, B. A. Whitton, and J. Bukowska, Use of the Algae for Monitoring Rivers III, Agence de l'Eau Artois Picardie, Douai Cedex, France, 1999.

[2] C. G. Ehrenberg, "Novorum generum et specierum brevis definition," Bericht über die zur Bekanntmachung geeigneten Verhandlungen der Königlich Preussischen Akademie der Wissenschaften zu Berlin, pp. 357-377, 1845.

[3] B. W. Skvortzow, "Diatoms from Calcutta, India," The Philippine Journal of Science, vol. 58, pp. 179-192, 1935.

[4] K. Biswas, "Common diatoms of the Loktak Lake, Manipur, Assam," Journal of the Royal Asiatic Society of Bengal, vol. 2, pp. 171-175, 1936.

[5] V. Krishnamurthy, "A contribution to the diatom flora of South India," Journal of the Indian Botanical Society, vol. 33, pp. 354381, 1954

[6] G. Venkataraman, Contribution to Our Knowledge of FreshWater Diatoms of South-India, Government Press, Madras, India, 1956.

[7] P. T. Sarode and N. D. Kamat, Freshwater Diatoms of Maharashtra, Saikripa Publications, Aurangabad, India, 1984.

[8] H. P. Gandhi, Freshwater Diatoms of Central Gujarat, Bishen Singh Mahendra Pal Singh, Dehradun, India, 1998.

[9] B. Karthick and J. P. Kociolek, "A new species of Pleurosigma from Western Ghats, South India," Beihefte zur Nova Hedwigia, vol. 141, pp. 117-124, 2012.

[10] B. Karthick and J. P. Kociolek, "Four new centric diatoms (Bacillariophyceae) from the Western Ghats, South India," Phytotaxa, vol. 22, no. 1, pp. 25-40, 2011.

[11] B. Karthick and J. P. Kociolek, "Reconsideration of the Gomphonema (Bacillariophyceae) species from Kolhapur, Northern Western Ghats, India: taxonomy, typification and biogeography of the species reported by H.P. Gandhi," Phycological Research, vol. 60, no. 3, pp. 179-198, 2012.

[12] B. Karthick, J. P. Kociolek, M. K. Mahesh, and T. V. Ramachandra, "The diatom genus Gomphonema Ehrenberg in India: checklist and description of three new species," Nova Hedwigia, vol. 93, no. 1-2, pp. 211-236, 2011.

[13] B. Karthick, P. B. Hamilton, and J. P. Kociolek, “Taxonomy and biogeography of some Surirella Turpin (Bacillariophyceae) taxa from Peninsular India," Nova Hedwigia, vol. 141, pp. 81-116, 2012.

[14] B. Karthick, R. Nautiyal, J. P. Kociolek, and T. V. Ramachandra, "Two new species of Gomphonema (Bacillariophyceae) from Doon Valley, Uttarakhand, India," Nova Hedwigia Beiheft, vol. 144, pp. 165-174, 2015.

[15] B. Alakananda, B. Karthick, J. C. Taylor, and P. B. Hamilton, "Two new species of Nitzschia from freshwater environs of Lonar Crater Lake, India," Phycological Research, vol. 63, no. 1, pp. 29-36, 2015.

[16] B. Alakananda, M. K. Mahesh, P. B. Hamilton, G. Supriya, B. Karthick, and T. V. Ramachandra, "Two new species of Nitzschia (Bacillariophyta) from shallow wetlands of Peninsular India," Phytotaxa, vol. 54, pp. 13-25, 2012.

[17] A. Z. Wojtal, H. Lange-Bertalot, R. Nautiyal, J. Verma, and P. Nautiyal, "Achnanthidium chitrakootense sp. nov. from rivers of northern and central India," Polish Botanical Journal, vol. 55, no. 1, pp. 55-64, 2010.

[18] S. Roy and J. P. Keshri, "Eco-taxonomic observations on Epithemia adnata (Kützing) brébisson (Bacillariophyta) from murguma reservoir, purulia, West Bengal; India," Phykos, vol. 45, no. 2, pp. 13-18, 2015. 
[19] B. N. Prasad, M. N. Srivastava, and P. Khanna, "Diatoms of Kalimpong, West Bengal (India)," Geophytology, vol. 18, no. 1, pp. 78-86, 1988.

[20] K. Krammer and H. Lange-Bertalot, "Bacillariophyceae," in Süsswasserflora von Mittleuropa, H. Ettl, J. Gerloff, H. Heynig, and D. Mollenhauer, Eds., pp. 1-610, Spektrum Akademischer, Heidelberg, Germany, 2000.

[21] J. C. Taylor, P. A. de la Rey, and L. van Rensburg, "Recommendations for the collection, preparation and enumeration of diatoms from riverine habitats for water quality monitoring in South Africa," African Journal of Aquatic Science, vol. 30, no. 1, pp. 65-75, 2005.

[22] B. Karthick, J. C. Taylor, M. K. Mahesh, and T. V. Ramachandra, "Protocols for collection, preservation and enumeration of diatoms from aquatic habitats for water quality monitoring in India," UP Journal of Soil and Water Sciences, vol. 3, no. 1, pp. 25-60, 2010.

[23] K. Buczkó, “The occurrence of the epiphytic diatom Lemnicola hungarica on different European Lemnaceae species," Fottea, vol. 7, no. 1, pp. 77-84, 2007.

[24] L. A. Carneiro and D. de Campos Bicudo, "O gênero Lemnicola (Bacillariophyceae) no Estado de São Paulo, Brasil," Hoehnea, vol. 34, no. 2, pp. 253-259, 2007.

[25] B. Karthick, P. B. Hamilton, and J. P. Kociolek, An Illustrated Guide to Common Diatoms of Peninsular India, Gubbi Labs, Gubbi, India, 2013.

[26] K. Krammer and H. Lange-Bertalot, "Bacillariophyceae, 3. Teil: Centrales, Fragilariaceae, Eunotiaceae," in Süsswasserflora von Mittleuropa Band 2/3 (Begründet von A. Pascher), H. Ettl, J. Gerloff, H. Heynig, and D. Mollenhauer, Eds., p. 576, Nachdr, Heidelberg, Germany, Akademischer, 1991.

[27] R. Patrick and C. W. Reimer, The Diatoms of the United States, vol. 1 of Monographs, Academy of Natural Sciences of Philadelphia, Philadelphia, Pa, USA, 1966.

[28] H. Lange-Bertalot, Diatoms of Europe-Navicula Sensu Stricto 10 Genera Separated from Navicula Sensu Lato Frustulia, A.R.G. Gantner Verlag K.G., Ruggell, Liechtenstein, 2001.

[29] H. Lange-Bertalot and D. Metzeltin, "Indicators of oligotrophy. 800 taxa representative of three ecologically distinct lake types," Iconographia Diatomologica, vol. 2, pp. 1-390, 1996.

[30] F. E. Round and P. W. Basson, "A new monoraphid diatom genus (Pogoneis) from Bahrain and the transfer of previously described species A. hungarica and A. taeniata to new genera," Diatom Research, vol. 12, no. 1, pp. 71-81, 1997.

[31] A. Z. Wojtal, L. Ector, B. Van de Vijver et al., "The Achnanthidium minutissimum complex (Bacillariophyceae) in southern Poland," Algological Studies, vol. 136/137, no. 1, pp. 211-238, 2011.

[32] F. E. Round, R. M. Crawford, and D. G. Mann, The Diatoms: Biology and Morphology of the Genera, Cambridge University Press, Cambridge, UK, 1990.

[33] L. K. Medlin and I. Kaczmarska, "Evolution of the diatoms: V. Morphological and cytological support for the major clades and a taxonomic revision," Phycologia, vol. 43, no. 3, pp. 245-270, 2004.

[34] H. P. Gandhi, "Some common freshwater diatoms from Gersoppa-falls (Jog-Falls)," Journal of the Poona University, Science Section, vol. 12, pp. 13-21, 1957.

[35] P. T. Sarode and N. D. Kamat, "Diatoms of Bidarbh, India-I," Bibliotheca Phycologica, vol. 66, pp. 259-319, 1983.

[36] H. P. Gandhi, "A further contribution to the diatom flora of the Jog Falls, Mysore State," Nova Hedwigia, vol. 31, pp. 633-652, 1970.
[37] H. P. Gandhi, "Notes on Diatomaceae from Ahmedabad and its environs-VI. On some diatoms from fountain reservoirs of Seth Sarabhai's Garden," Hydrobiologia, vol. 30, no. 2, pp. 248272, 1967.

[38] H. P. Gandhi, "On the diatom flora of some ponds around Vasna Village near Ahmedabad," Journal of the Indian Botanical Society, vol. 39, pp. 558-567, 1960.

[39] H. P. Gandhi, "Freshwater diatoms from Kolhapur and its immediate environs," Journal of the Bombay Natural History Society, vol. 55, pp. 493-511, 1958.

[40] H. P. Gandhi, "Some fresh-water diatoms from Lonavla HillStation in the Bombay-State (Maharashtra)," Hydrobiologia, vol. 20, no. 2, pp. 128-154, 1962.

[41] P. T. Sarode and N. D. Kamat, "Diatoms of Marathwada, Maharashtra-I," Phykos, vol. 18, no. 1-2, pp. 25-32, 1979.

[42] P. T. Sarode and N. D. Kamat, "The diatom flora of Nagpur, India," Nova Hedwigia, vol. 32, pp. 797-838, 1980.

[43] H. P. Gandhi, "The freshwater diatoms flora of the Hirebhasgar Dam area, Mysore State," Journal of the Indian Botanical Society, vol. 37, pp. 249-265, 1958.

[44] H. P. Gandhi, "The diatom flora of the Bombay and Salsette islands. II," Nova Hedwigia, vol. 3, pp. 469-505, 1962.

[45] M. E. C. Johnson, "Algal flora of Banjara and Nadimi lakes," Journal of the Indian Botanical Society, vol. 85, pp. 103-106, 2006.

[46] E. A. Gonzalves and H. P. Gandhi, "A systematic account of the diatoms of Bombay and Salsette-I," Journal of the Indian Botanical Society, vol. 31, pp. 117-115, 1952.

[47] M. R. Suxena and V. Venkateswarlu, "Diatoms of the hot springs of badrinath, himalayas, diatomaceae II," Friedrich Hustedt Gedenkband, Nova Hedwigia, vol. 31, pp. 633-665, 1970, (including 6 plates), 1970.

[48] M. R. Suxena, "Algae from kodaikanal hill, South India," Bibliotheca Phycologica, vol. 66, pp. 43-99, 1983, (including 8 plates), J. Cramer, 1983.

[49] H. P. Gandhi, "Notes on the Diatomaceae of Ahmedabad and its environs," Hydrobiologia, vol. 17, no. 3, pp. 218-236, 1961.

[50] R. K. Dwivedi and P. K. Misra, "On the occurrence of freshwater diatoms of Southern Himachal Pradesh, India," Phykos, vol. 44, no. 1, pp. 17-24, 2014. 

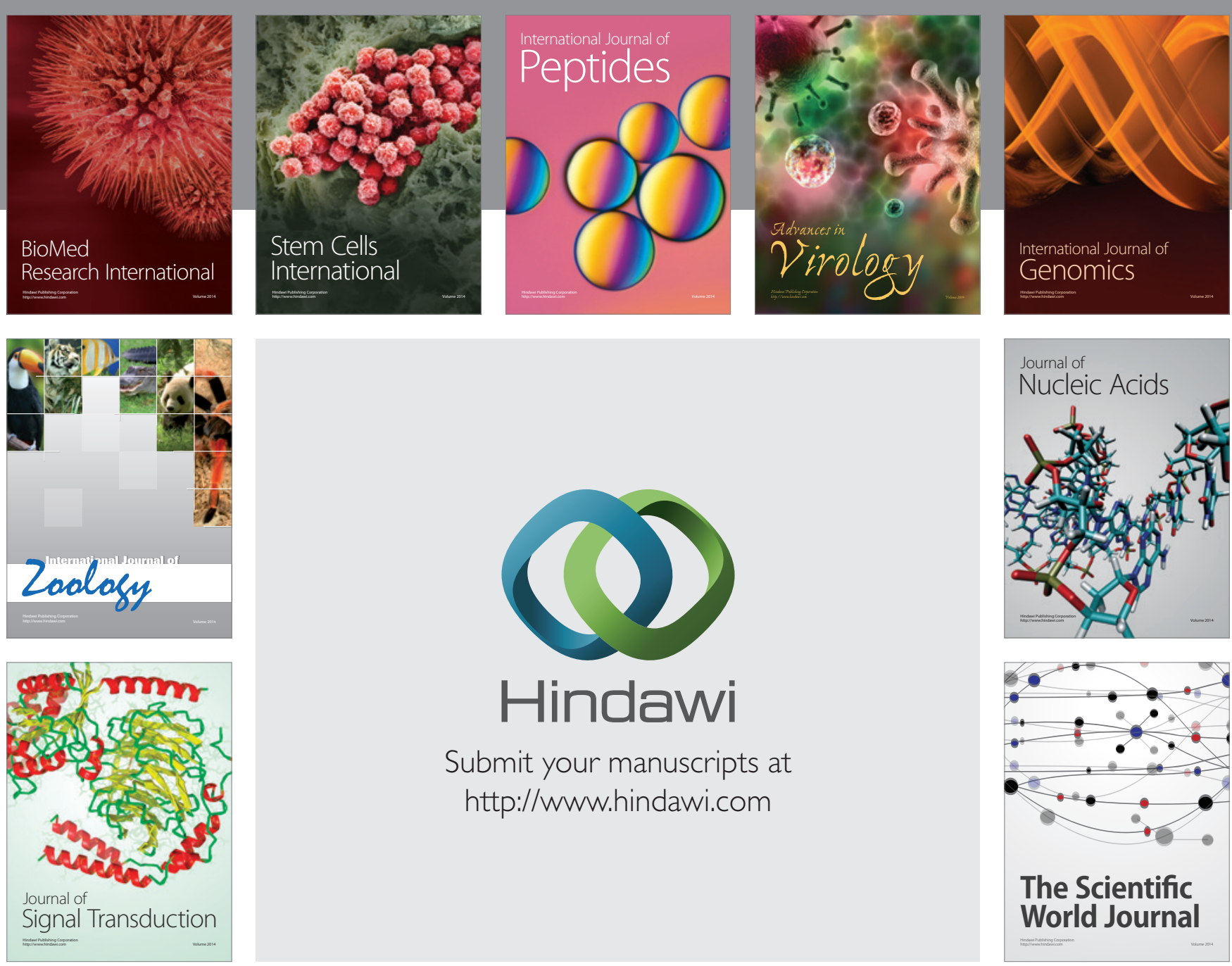

Submit your manuscripts at

http://www.hindawi.com
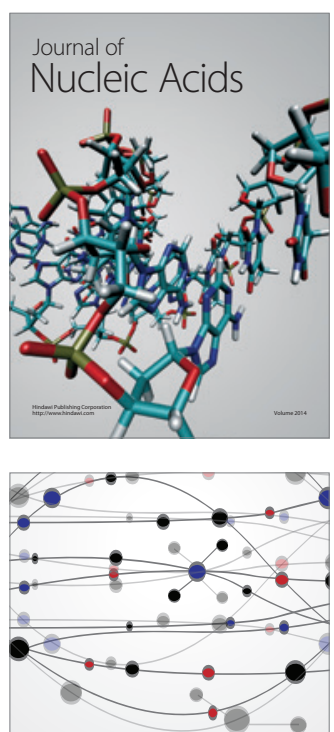

The Scientific World Journal
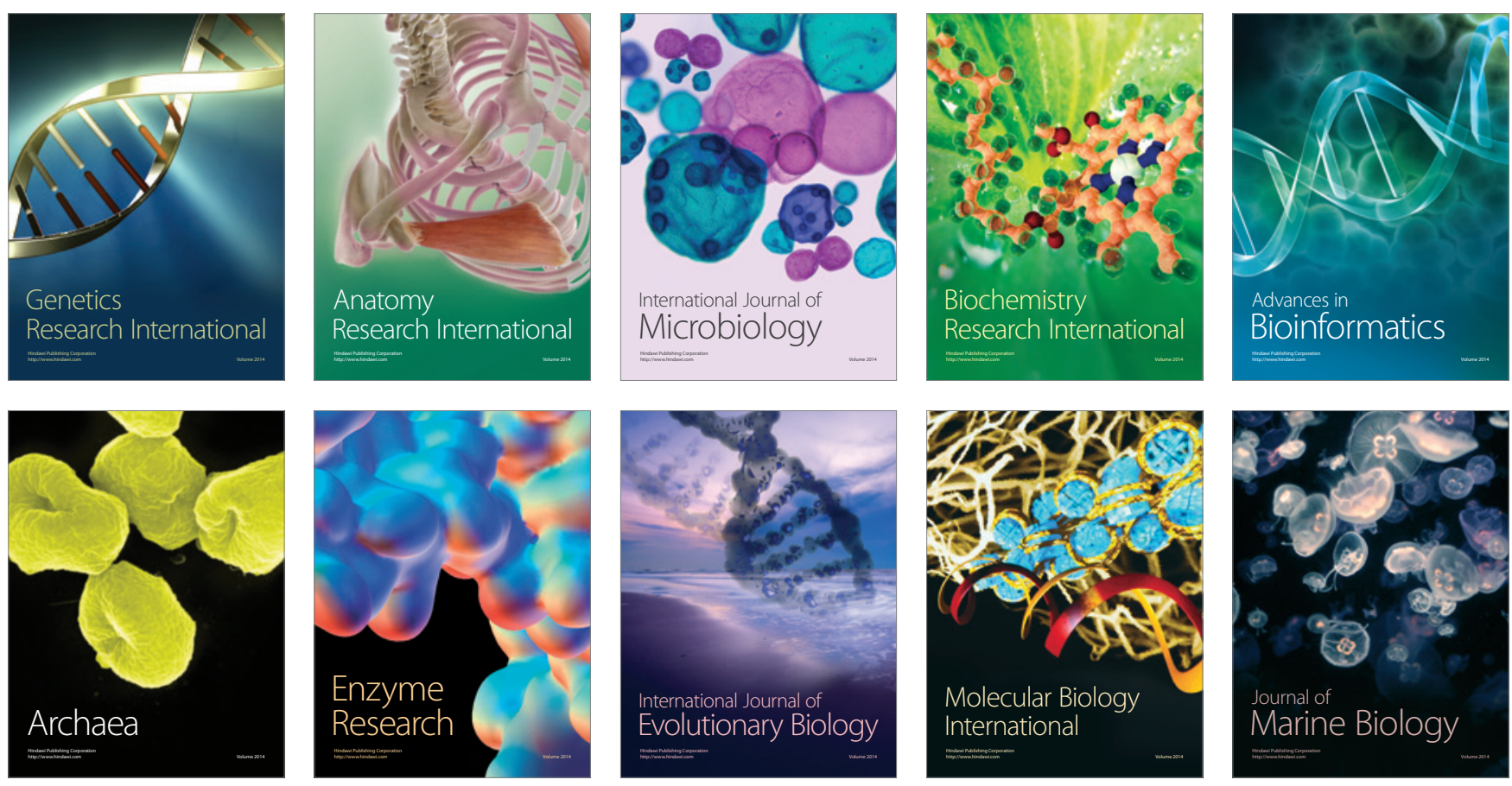